\title{
EVALUATING PLANT INVASIONS FROM BOTH HABITAT AND SPECIES PERSPECTIVES
}

\author{
Geneva W. Chong1,2, Yuka Otsuki², Thomas J. Stohlgren ${ }^{3}$, Debra Guenther ${ }^{2}$, \\ Paul Evangelista ${ }^{2}$, Cynthia Villa ${ }^{2}$, and Alycia Waters ${ }^{2}$
}

\begin{abstract}
AвsтRACT.-We present an approach to quantitatively assess nonnative plant invasions at landscape scales from both habitat and species perspectives. Our case study included 34 nonnative species found in 142 plots ( 0.1 ha) in 14 vegetation types within the Grand Staircase-Escalante National Monument, Utah. A plot invasion index, based on nonnative species richness and cover, showed that only 16 of 142 plots were heavily invaded. A species invasive index, based on frequency, cover, and number of vegetation types invaded, showed that only 7 of 34 plant species were highly invasive. Multiple regressions using habitat characteristics (moisture index, elevation, soil P, native species richness, maximum crust development class, bare ground, and rock) explained $60 \%$ of variation in nonnative species richness and $46 \%$ of variation in nonnative species cover. Three mesic habitats (aspen, wet meadow, and perennial riparian types) were particularly invaded (31 of 34 nonnative species studied were found in these types). Species-specific logistic regression models for the 7 most invasive species correctly predicted occurrence $89 \%$ of the time on average (from $80 \%$ for Bromus tectorum, a habitat generalist, to $93 \%$ for Tamarix spp., a habitat specialist). Even with such a modest sampling intensity $(<0.1 \%$ of the landscape), this multiscale sampling scheme was effective at evaluating habitat vulnerability to invasion and the occurrence of the 7 most invasive nonnative species. This approach could be applied in other natural areas to develop strategies to document invasive species and invaded habitats.
\end{abstract}

Key words: invasive species, cheatgrass, Bromus tectorum, tamarisk, Tamarix spp., nonnative species, exotic species, Grand Staircase-Escalante National Monument, multiscale sampling, modified-Whittaker plots, biological soil crusts.

Biological invasions have been suggested as one of the major global environmental changes of our time. Human activities have caused the breakdown of barriers to species dispersal at a global scale, and invasions have ramifications at all levels of organization from the gene to the landscape (D'Antonio and Vitousek 1992). Research on nonnative species invasions has addressed 3 main areas (DeFerrari and Naimen 1994): (1) species characteristics as well as genetic and ecophysiological characteristics of invaders (Barrett and Richardson 1986, Newsome and Noble 1986, Roy 1990); (2) habitat characteristics and properties of invaded communities (Swincer 1986, Crawley 1987, and Rejmánek 1989); and (3) ecological, economic, and social impacts of invasions (Elton 1958, Office of Technology Assessment 1993, Vitousek et al. 1997, Stohlgren et al. 1997, 1999a, Pimentel et al. 2000, Rejmánek and Pitcairn 2002). Despite the widespread interest in invasions, there are few tools to assist land managers with setting priorities for invasive species management (Lee 2001). Therefore, since it is the interactions between species and their habitats that determine invasion success (Lodge 1993), combining scientific information on which habitats might be more vulnerable to invasion and which nonnative species have the potential to become successful invaders would greatly benefit resource managers.

While many agencies have lists of nonnative species whose importation should be controlled or whose eradication is a top priority (D'Antonio 1997), only a few species are able to establish and successfully invade in a new range (Cronk and Fuller 1995, Williamson and Fitter 1996, Lodge 2000, Mack et al. 2000). It is also clear that nonnative species are not randomly distributed at global (Lonsdale 1999), regional (Stohlgren et al. 1999a), or local scales (Stohlgren et al. 1997). Thus, some habitats, such as riparian zones in the Central Grasslands of the U.S. (Stohlgren et al. 1998a), are far more heavily invaded than other habitats in the same landscape (Planty-Tabacchi et al. 1996, Stohlgren et al. 2001). Developing synthetic approaches to describe spatial patterns of nonnative species

\footnotetext{
1Present address: Northern Rocky Mountain Science Center, U.S. Geological Survey, Box 173492, Montana State University, Bozeman, MT, 59717-3492.

${ }^{2}$ Natural Resource Ecology Laboratory, Colorado State University, Fort Collins, CO 80523-1499.

${ }^{3}$ Fort Collins Science Center, U.S. Geological Survey, 2150 Centre Ave., Bldg. C, Fort Collins, CO 80526-8118.
} 
will provide resource managers with a tool for identifying areas that may warrant more intensive nonnative species management.

\section{Identifying Habitats \\ Vulnerable to Invasion}

Environmental and habitat characteristics may predispose a habitat to invasion by nonnative plant species (Panetta and Mitchell 1991). For example, temperature, moisture, wind, light, soil type, vegetation community type, and disturbance history are all recognized as important factors in invasions (Fox and Fox 1986, Hobbs 1991, Hobbs and Huenneke 1992, DeFerrari and Naimen 1994, Burke and Grime 1996). Theories (Case 1990), observations on islands (Elton 1958), and small-scale experiments (Tilman 1999) have suggested that areas of high plant diversity might be immune to invasion. However, the most heavily invaded habitats in the Central Grasslands and Rocky Mountains are those with high native species richness, high soil fertility, and high light availability (Stohlgren et al. 1997, 1998b, 1999a). Therefore, contradictions among studies have resulted in the slow emergence of generalizations in habitat invasion (Usher 1988, Lodge 1993, Lonsdale 1999, Stohlgren et al. 1998a, 1999a, 1999b) as well as mechanisms explaining these patterns (Mack et al. 2000).

Identifying habitats vulnerable to invasion is especially challenging in large natural landscapes. Yet the habitat approach may be a crucial component of a strategy to control invasions (Panetta and Mitchell 1991, Hobbs and Humphries 1995, Williamson and Fitter 1996, Lonsdale 1999, Davis et al. 2000) if it allows resource managers to find and control nonnative species before they dominate a site (Rejmánek and Pitcairn 2002). Often, no single measure will be sufficient in itself; thus, an integrated approach for finding invasive plants needs to be developed (Hobbs and Humphries 1995).

\section{Identifying Highly Invasive Plant Species}

Many studies have suggested that some general invasive traits of nonnatives must exist and need to be determined to assess potentials to invade relative to other species in a species pool. Such traits might include small seeds, high seed viability, rapid establishment and growth, shade tolerance, and short times to reproductive maturity (Lee 2001). However, these efforts have evaluated relatively few nonnative plant species in few environments and have been unsuccessful in describing general traits of these species.

Unsuccessful attempts to generalize invader traits have been attributed to 3 factors. First, many nonnative species with such recognized traits are not yet successful in many new habitats. Second, many species lack most of the "ideal" traits and still are successful (e.g., kudzu), or vice versa. Third, certain species traits are more important in some habitats than others, and thus habitat factors need to be integrated with a species approach (Lee 2001). While the continued development of tools to assess individual species' invasibility is an important management strategy (Hobbs and Humphries 1995), the efforts must incorporate other components such as responses of invaders to particular habitat characteristics, disturbance regimes, and site history (Hobbs and Humphries 1995). It is crucial to learn more about the interaction of the invader and its target habitat (Lodge 1993).

\section{Combining Species and Habitat Approaches}

This study examines landscape-scale patterns of nonnative plant locations in a wide array of habitats in the Grand StaircaseEscalante National Monument, Utah, to evaluate plant invasions from both habitat and species approaches. The purpose of this research was to (1) identify successfully invaded habitats in a 150,000-ha portion of the Grand StaircaseEscalante National Monument; (2) identify successfully invading species in the study area; (3) develop generalized models of plant invasions in the study area based on habitat characteristics (geography, native vegetation structure and diversity, biological soil crust development and cover, and soils characteristics); and (4) test the general models of plant invasion in the study area on individual invasive species. We hypothesized that nonnative species locations are not random on the landscape and that areas more vulnerable to invasion can be identified based on habitat characteristics that can be measured in the field.

\section{Methods \\ Study Site}

The Grand Staircase-Escalante National Monument (hereafter Monument) is located in 


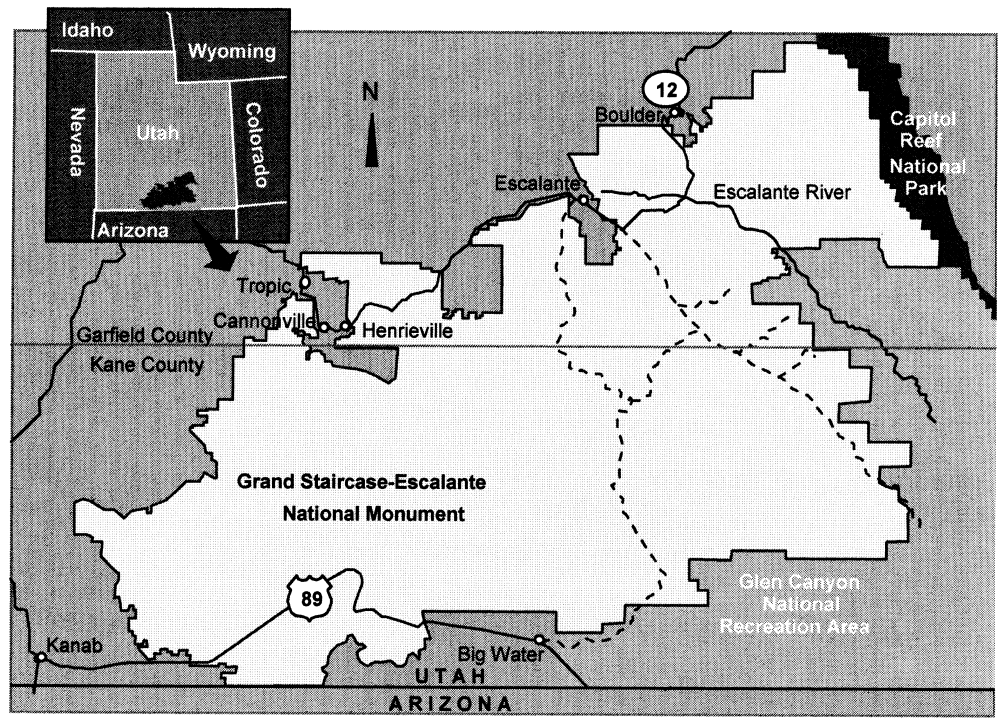

Fig. 1. Grand Staircase-Escalante National Monument, Utah, study area.

south central Utah, USA (Fig. 1), and primarily consists of an arid landscape with an abundance of variable, isolated habitats. The Monument covers approximately 849,870 ha and ranges in elevation from $1200 \mathrm{~m}$ to $2530 \mathrm{~m}$. The area contains more than 1100 species of vascular plants, which is $30 \%$ of the Utah flora (Shultz 1998). The long-term annual precipitation in the neighboring town of Escalante, Utah, averaged $231 \mathrm{~mm}$ from 1901 to 1994 (missing 1920, 1943, and 1944) and totaled $312 \mathrm{~mm}$ (1998) and $277 \mathrm{~mm}$ (1999) during the study period. This study was conducted in the eastern one-third of the Monument, which contains most of the Escalante Canyon region and the northeast corner of the Kaiparowits Plateau.

\section{Plot Selection}

We sampled 142 vegetation plots $(0.1$ ha each) during May through July 1998 and 1999. In 1998, we sampled 97 plots from 12 vegetation types. We used a simple random study design with unbiased site selection to locate 50 plots. The majority of these plots occurred in the 3 most common vegetation types: blackbrush (Coleogyne ramosissima), sagebrush (Artemisia tridentata), and pinyon-juniper (Pinus edulis-Juniperus osteosperma). We used the locations of the 50 plots to subjectively locate 47 plots nearby but in different vegetation types or topographic positions (e.g., wash versus upland). Three of the original 50 plots did not have significantly different areas nearby. We chose 47 new plots to reduce travel cost and to increase the sample size in habitats that are typically missed with random sampling because they cover a small area (e.g., drainage features in an arid environment). For example, after sampling a randomly selected pinyon pine site, we would look for a nearby but different site (e.g., lowland riparian) to sample. In 1999 we used stratified random selection to locate 45 study plots based on dominant vegetation types mapped in the Monument.

The combined 142 plots were classified into 14 major vegetation types identified by dominant species, 3 vegetation structure types (tree-, shrub-, or herbaceous-dominated), and 2 topographic positions (upland versus lowland wash). The vegetation types were assigned moisture index values as an indication of the moisture gradient that we sampled. Values ranged from 1 to 10 for xeric vegetation types and from 11 to 14 for mesic vegetation types (Table 1).

\section{Vegetation Sampling}

We used a $1000-\mathrm{m}^{2}(20 \times 50-\mathrm{m})$ modifiedWhittaker plot to sample each site (Stohlgren et al. 1998a). Plots were placed to facilitate plant species heterogeneity within the plot and thus increase the number of species encountered. Nested in each plot were ten $1-\mathrm{m}^{2}(0.5 \times 2-\mathrm{m})$ subplots, two $10-\mathrm{m}^{2}(2 \times 5-\mathrm{m})$ subplots, and 
TABLE 1. Summary characteristics of 14 different vegetation types in Grand Staircase-Escalante National Monument. We calculated mean values of native and nonnative species richness and cover for each $1000-\mathrm{m}^{2}$ plot $(n=$ number of plots). Total nonnative species richness within the same vegetation type is shown as Cumulative nonnative spp. Vegetation types also represent general moisture (Moisture index); higher values indicate more moist sites. Standard errors are shown in parentheses. Analysis of variance (ANOVA) was used to compare differences in means within the same columns.

\begin{tabular}{|c|c|c|c|c|c|c|c|}
\hline \multirow{2}{*}{$\begin{array}{l}\text { Moisture } \\
\text { index }\end{array}$} & \multirow{2}{*}{$\begin{array}{l}\text { Vegetation } \\
\text { type }\end{array}$} & \multirow[b]{2}{*}{$n$} & \multirow{2}{*}{$\begin{array}{c}\text { Cumulative } \\
\text { nonnative spp. }\end{array}$} & \multicolumn{2}{|c|}{$\begin{array}{l}\text { Mean species richness } \\
\text { per plot }\end{array}$} & \multicolumn{2}{|c|}{$\begin{array}{l}\text { Mean } \% \text { cover } \\
\text { per plot }\end{array}$} \\
\hline & & & & Native & Nonnative & Native & Nonnative \\
\hline 1 & Desert shrub & 16 & 7 & $28(1.5)$ & $2(0.2)$ & $26(3.9)$ & $2.0(0.6)$ \\
\hline 2 & Blackbrush & 22 & 3 & $22(1.3)$ & $1(0.1)$ & $30(2.3)$ & $3(1.0)$ \\
\hline 3 & Mixed shrub & 5 & 3 & $26(1.8)$ & $1(0.3)$ & $19(5.1)$ & $<1(0.03)$ \\
\hline 4 & Sagebrush & 12 & 5 & $27(1.9)$ & $1(0.3)$ & $33(4.1)$ & $5(1.7)$ \\
\hline 5 & Juniper & 17 & 9 & $29(1.6)$ & $2(0.5)$ & $24(3.7)$ & $4(1.7)$ \\
\hline 6 & Pinyon-juniper & 30 & 8 & $27(1.1)$ & $1(1.6)$ & $19(2.4)$ & $1(0.5)$ \\
\hline 7 & Pinyon & 8 & 12 & $33(1.7)$ & $4(0.8)$ & $33(7.8)$ & $4(1.3)$ \\
\hline 8 & Pinyon-juniper-oak & 5 & 4 & $39(3.5)$ & $1(0.6)$ & $20(4.7)$ & $<1(0.3)$ \\
\hline 9 & Ponderosa pine & 2 & 1 & $37(6.0)$ & $1(0)$ & $48(16.8)$ & $3(1.5)$ \\
\hline 10 & Manzanita & 2 & 0 & $32(3.0)$ & $0(0)$ & $40(3.6)$ & $0(0)$ \\
\hline 11 & Rabbitbrush & 8 & 12 & $26(1.5)$ & $3(0.9)$ & $23(4.6)$ & $8(3.6)$ \\
\hline 12 & Aspen & 6 & 15 & $35(3.7)$ & $6(1.4)$ & $44(11)$ & $11(3.4)$ \\
\hline 13 & Wet meadow & 4 & 19 & $32(4.2)$ & $8(1.2)$ & $36(10)$ & $24(8.0)$ \\
\hline \multirow[t]{4}{*}{14} & Perennial riparian & 5 & 18 & $35(4.3)$ & $10(1.1)$ & $47(4.8)$ & $12(2.6)$ \\
\hline & ALL TYPES & 142 & 34 & $28(0.6)$ & $2(0.2)$ & $27(1.6)$ & $4(0.6)$ \\
\hline & ANOVA & $F$-ratio & & 4.74 & 20.16 & 3.16 & 7.04 \\
\hline & & $P<$ & & 0.001 & 0.001 & 0.001 & 0.001 \\
\hline
\end{tabular}

one $100-\mathrm{m}^{2}(5 \times 20-\mathrm{m})$ subplot. Projected foliar cover for each understory and shrub species and surface cover of bare ground were estimated to the nearest percent in the $1-\mathrm{m}^{2}$ subplots. This level of precision was achieved through training the eye to recognize a $10 \times$ $10-\mathrm{cm}$ area, which was $1 \%$ of the subplot. Species with $<1 \%$ cover in a subplot were assigned a cover value of $0.5 \%$. We indentified plant species in the field following Welsh et al. (1993) and defined nonnative species as those species not present before European settlement. On average, $10 \%$ of specimens were unidentifiable to species each year due to lack of distinguishing parts or inappropriate phenological stage of the plants during sampling.

We also measured biological soil crust cover according to a development stage gradient (USDI 1995; J. Belnap personal communication) in the $1-\mathrm{m}^{2}$ subplots. Younger crusts (development stages 1-4) were relatively flat and light colored, whereas older, well-developed crusts (development stages 6-20) were considerably darker or bumpier and may have had associated mosses and lichens.

Cumulative plant species presence and the presence of biological soil crust development stages were noted in the $10-\mathrm{m}^{2}$ and $100-\mathrm{m}^{2}$ subplots and in the entire $1000-\mathrm{m}^{2}$ plot. Species and crust classes present only in the larger subplots $\left(10-\mathrm{m}^{2}, 100-\mathrm{m}^{2}\right)$ or in the entire $1000-\mathrm{m}^{2}$ plot were assigned a cover value of $1 \%$ for analyses.

Ancillary data recorded for each plot included slope, aspect, and UTM coordinates from a global positioning system (GPS). We used UTM coordinates to determine plot elevations from digital elevation models in a geographic information system (GIS).

\section{Soil Sampling}

Five soil samples, 1 in each corner and 1 in the center, from each modified-Whittaker plot were taken with a $2.5-\mathrm{cm}$-diameter core to a depth of $15 \mathrm{~cm}$ and pooled into 1 composite sample. We then analyzed soils for indicators of nutrient and moisture availability. We airdried samples for at least 48 hours and sieved them to $2 \mathrm{~mm}$ (number 10 standard sieve). Particle size was determined using the standard hydrometer method (Gee and Bauder 1986). For soil carbon, nitrogen, and phosphorus, we ground soils to a fine powder and then oven-dried them at $55^{\circ} \mathrm{C}$ for 48 hours. We analyzed samples for percent total carbon and nitrogen using a LECO-1000 CHN analyzer 
(LECO Corporation, Saint Joseph, Missouri, USA). Inorganic carbon from carbonates was determined using a volumetric method (Wagner et al. 1998). Organic carbon was calculated as the difference between total and inorganic carbon. Soil phosphorus was determined colorimetrically from a sodium bicarbonate extraction (Kou 1996).

\section{Statistical Analyses}

All statistical analyses were performed using SYSTAT 9.0 with $\alpha=0.05$ (SYSTAT 1999). Variables were tested for normality and transformed using $\log _{10}(\mathrm{x}+1)$ or square root transformations to better approximate normality when needed. To examine general trends in the dataset, we calculated mean nonnative species richness and mean nonnative foliar cover for each vegetation type, and conducted analysis of variance (ANOVA) to compare these values.

Plot INVASIVE INDEX AND SPECIES INVASION INDEX.-We developed 2 indices to distinguish the most heavily invaded vegetation types, termed the Plot Invasion Index (PII), and the most successful invading species, termed the Species Invasive Index (SII). The PII was calculated by multiplying total nonnative species richness per plot by total foliar cover for those species per plot (Lee 2001). The SII value was calculated by multiplying cumulative foliar cover, frequency in the plots, and number of vegetation types invaded (Lee 2001). Thus, those species considered "invasive" are characterized by high foliar cover (i.e., high SII value) and establishment in many plots and vegetation types.

MULTIPLE REGRESSION AND REGRESSION TREE ANALYSES. - To learn more about the relationship between all the environmental variables measured in the field and nonnative species richness and cover, we performed stepwiseforward multiple regression and regression tree analyses. Multiple regression allows the simultaneous testing and modeling of multiple independent variables. Regression tree analysis works by assembling all subplots into a single cluster and then separating them by attribute into a hierarchical binary tree. Therefore, the terminus of each branch of the tree will represent a cluster of plots that are more similar to each other than to a member of the twin cluster. This type of analysis is able to identify key independent variables from the list of variables identified in multiple regression analysis (Lee 2001). Regression tree analysis helps to demonstrate the relationships between certain environmental characteristics and nonnative invasive patterns at landscape scales using fewer variables than multiple regression.

Cluster ANALYSIS.-Data on cumulative foliar cover, plot frequency, number of vegetation types invaded, and maximum percent cover were used in K-mean cluster analysis to group nonnative species into 4 distinct groups. K-mean cluster analysis was used because it produced a set number of different clusters of greatest possible distinction by maximizing between-cluster variation and minimizing withincluster variation (SYSTAT 1999). All nonnative species could be classified into 4 groups following this analysis: (1) dominant generalists (i.e., high frequency and cover), (2) subdominant generalists (i.e., high frequency and low cover), (3) specialists (i.e., low frequency and high cover), and (4) rare or transient species (i.e., low frequency and $<1 \%$ cover). We performed an ANOVA to test the differences in means of each data category among the 4 groups. Tukey's HSD method was used to compare cluster means if the ANOVA indicated statistical significance $(P<0.05)$.

SELECTED INVASIVE SPECIES AND LOGISTIC REGRESSION.-Seven nonnative invasive species (Bromus tectorum, Erodium cicutarium, Poa pratensis, Salsola iberica, Tamarix spp., Taraxacum officinale, Tragopogon dubius) were selected for more intensive study because they were found in more than 10 plots. The 7 species selected had high SII scores and represented 3 of the 4 groups classified previously: 1 dominant generalist, 4 subdominant generalists, and 2 specialists. The stepwise-forward multiple regression models originally used to predict nonnative species richness and cover in the previous analysis were then used to predict patterns of the 7 nonnative species. Because these models had a low explanatory power, we focused on logistic regression models to better explain patterns for each of the 7 selected species.

We used stepwise forward logistic regression to describe patterns of invasion by identifying significant predictor variables for each of the 7 species. Logistic regression creates a model used to study the association between a binary response and a set of independent variables. Therefore, each plot was given a binary 
value for each of the 7 species to indicate presence $($ value $=1)$ or absence $($ value $=0$ ). The primary output used from this analysis consisted of McFadden's Rho-squared values and a prediction success table. The McFadden Rho-squared value is a transformation of the likelihood statistic intended to mimic a standard coefficient of determination $(R$-squared value). Therefore, a higher value corresponds to more significant results. However, Rhosquared values between 0.20 and 0.40 are generally considered very satisfactory (Hensher and Johnson 1981). The prediction success table summarizes the classificatory power of the model and includes additional analytical results on the ability of the model to successfully predict occurrence and the gain that this model shows over a purely random model. Results from the logistic regression models were compared to results from the multiple regression analyses to examine whether the same predictors were identified as significant.

A complete logistic regression was then run 4 times for each of the selected species using significant variables identified in the previous analyses: (1) multiple regression model for nonnative species richness, (2) multiple regression model for nonnative species cover, (3) regression tree model for nonnative species richness, and (4) regression tree model for nonnative species cover. Results from the logistic analyses were then compared with the results from the cluster analyses to see if we could generalize the relationships between habitat characteristics and nonnative species patterns (clusters).

\section{RESUlTS}

\section{Identifying Successfully Invaded Habitats}

Nonnative species richness and cover were generally highest in the most mesic sites. Nine of the top 10 invaded plots from the PII list were located in mesic vegetation types (moisture index $>10$; Table 1). The only exception was a plot heavily invaded by Bromus tectorum located in the transition between juniper (Juniperus sp.; moisture index $=5$ ) and rabbitbrush (Chrysothamnus sp.; moisture index $=11$ ) vegetation types. In general, high PII values in xeric vegetation types were a result of high B. tectorum cover. Upland vegetation types with lower moisture indices $(<10)$ generally contained fewer than 2 nonnative species per plot. An exception was the pinyon type, due to higher numbers of nonnative species in plots located in washes (slight topographic depressions that channel and collect water during storm events). We found 14 nonnative species in only mesic vegetation types, 7 of which occurred in only a single vegetation type (4 species in aspen, 1 species each in the rabbitbrush, wet meadow, and perennial riparian types). Two nonnative species were specific to the upland sites, and 17 species occurred in both mesic and xeric vegetation plots.

GENERALIZED MODELS OF PLANT INVASIONS BASED ON HABITAT CHARACTERISTICS.-Stepwiseforward multiple regression identified 7 habitat variables that explained $60 \%$ of variance in nonnative species richness (Table 2). Soil phosphorus (standard coefficient $=0.40$ ) and moisture index (standard coefficient $=0.32$ ) were positively correlated with nonnative species, while elevation was negatively correlated (standard coefficient $=-0.36$ ). The same set of habitat characteristics (except for native species richness) was identified to explain $46 \%$ of variation in foliar cover of nonnative species (Table 2). Percent bare ground had the highest standard coefficient $(-0.38)$. In general, we encountered greater numbers and cover of nonnative species in mesic vegetation types and in areas with higher soil phosphorous values. Invasion was generally more successful in plots with less developed biological soil crusts (negative standard coefficients), with the exception of B. tectorum (Table 4).

Regression tree analyses provided another way to view the relationships between environmental factors and plot invasion. In the model for nonnative species richness (Fig. 2), the soil moisture index and phosphorus defined a tree with a proportional reduction in error (PRE) of 0.57. PRE values (similar to $R^{2}$ values) were calculated to determine the amount of variation explained by the independent variables in the model (Hansen et al. 1996). Therefore, over half the variance in nonnative species richness could be explained with only 2 habitat characteristics. As in the regression model, mesic vegetation types with a moisture index $>12$ provided the clearest split between groups, relating more strongly to nonnative species richness than less moist sites. Among drier vegetation types, sites with higher soil 
TABLE 2. Multiple linear regression results for explaining nonnative species richness and cover from habitat characteristics. Most values were transformed prior to analysis.

\begin{tabular}{|c|c|c|c|c|}
\hline $\begin{array}{l}\text { Dependent variable/ } \\
\text { habitat characteristics }\end{array}$ & Coefficient & Standardized coefficient & $t$ & $P$-value \\
\hline \multicolumn{5}{|c|}{ Nonnative species richness (model $R^{2}=0.60, F_{7,130}=30.8, P<0.001$ ) } \\
\hline Moisture index & 0.024 & 0.318 & 5.18 & 0.001 \\
\hline Elevation $(\mathrm{m})$ & 0 & -0.359 & -4.99 & 0.001 \\
\hline$\%$ soil phosphorus & 0.308 & 0.396 & 5.27 & 0.001 \\
\hline Native species richness & 0.006 & 0.154 & 2.57 & 0.011 \\
\hline Maximum crust development class & -0.021 & -0.161 & -2.72 & 0.007 \\
\hline$\%$ bare ground & -0.005 & -0.306 & -4.82 & 0.001 \\
\hline$\%$ rock & -0.006 & -0.285 & -4.74 & 0.001 \\
\hline \multicolumn{5}{|c|}{ Nonnative species cover $\left(\right.$ model $\left.R^{2}=0.46, F_{6,131}=20.4, P<0.001\right)$} \\
\hline Moisture index & 0.023 & 0.18 & 2.62 & 0.01 \\
\hline Elevation $(\mathrm{m})$ & 0 & -0.196 & -2.41 & 0.017 \\
\hline$\%$ soil phosphorus & 0.341 & 0.262 & 2.99 & 0.003 \\
\hline Maximum crust development class & -0.049 & -0.228 & -3.32 & 0.001 \\
\hline$\%$ bare ground & -0.01 & -0.384 & -5.21 & 0.001 \\
\hline$\%$ rock & -0.009 & -0.268 & -3.82 & 0.001 \\
\hline
\end{tabular}

phosphorus ( 2 splits: $>1.22$ and $>0.65)$ had higher nonnative richness than sites with less phosphorus.

The 2nd model, with nonnative foliar cover as a dependent variable, resulted in 3 variables defining the decision tree with $\mathrm{PRE}=0.45$ (Fig. 3). Again, higher nonnative cover was found in mesic vegetation types with a moisture index $>11$. Among xeric vegetation types, plots with less bare soil and higher soil phosphorus had more nonnative cover.

\section{Identifying Successful Invading Species}

From 142 plots (each $1000 \mathrm{~m}^{2}$ ), we identified 519 species in 14 different vegetation types. Thirty-four species were nonnatives from 14 families. The single most dominant nonnative plant species was $B$. tectorum, with $65 \%$ of the total nonnative species cover on the landscape $($ mean $=3 \% \pm 0.5 \%$ per plot). Only 2 native species had similar mean cover: Artemisia tridentata $(3 \% \pm 0.6 \%)$ and Coleogyne ramosissima $(3 \% \pm 0.8 \%)$. Bromus tectorum and the native Gutierrezia sarothrae were the most frequently encountered species, occurring in $80 \%$ of the plots. Only 4 species were found in more than $10 \%$ of the plots (>14 plots); we encountered 29 nonnative species in less than $7 \%$ of study plots. Several frequently encountered species had low foliar cover. For example, Tragopogon dubius was found in 22 plots (2nd highest) but averaged $<1 \%$ cover. In contrast, Festuca pratensis had the highest mean foliar cover $(5 \%$ in plots where it occurred) but was encountered in only 2 plots. The Species Invasive Index (SII) had a highly skewed distribution (most species had SII close to zero) with only 7 focal species having values much greater than zero. The SII ranged from 0 to $5000\left(\bar{x}=500, s_{\bar{x}}=195\right)$ when the outlier Bromus tectorum was not included.

TESTING THE GENERAL MODELS OF PLANT INVASION FOR INDIVIDUAL NONNATIVE SPECIES.Cluster analysis singled out B. tectorum as the only dominant generalist from our nonnative species list (Table 3). This widespread annual grass occupied 114 plots in 13 of 14 vegetation types. The subdominant generalist group contained 8 species, with an average plot frequency of $<8 \%$. The 6 species clustered in the specialist group had plot and habitat frequencies similar to the subdominant generalists, but they had relatively high mean cumulative cover and maximum foliar cover. The other 19 species clustered in the transient group had low values in all categories.

Logistic regression analyses for all 7 focal species resulted in Rho-squared values within a satisfactory range $(0.34-0.62$; Hensher and Johnson 1981) and produced models that correctly predicted occurrence $89 \%$ of the time on average (Table 4).

Bromus tectorum (dominant generalist): Logistic regression analysis identified 6 variables for predicting the presence of $B$. tectorum 


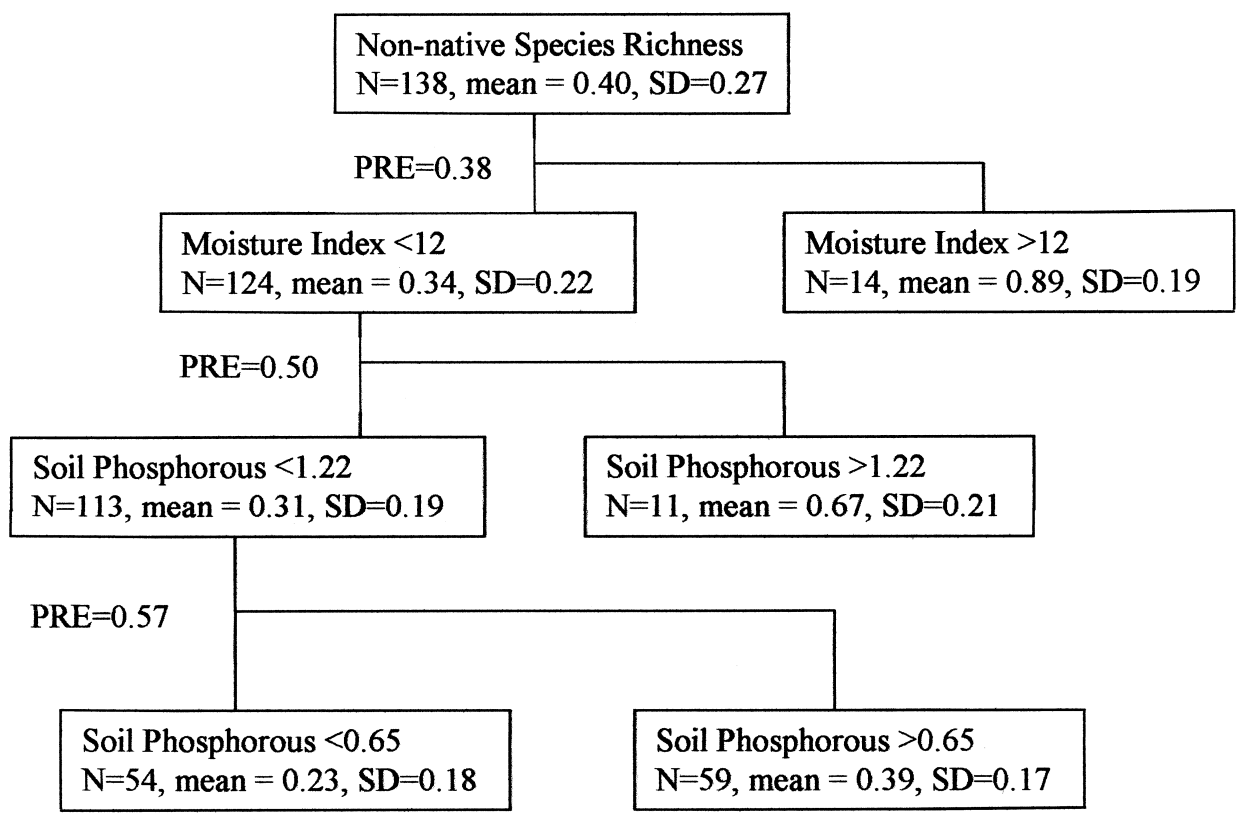

Fig. 2. Regression tree analysis with $\log _{10}$ Nonnative Species Richness as the dependent variable. Moist sites are most heavily invaded, while drier sites with less soil phosphorus are less heavily invaded.

(Table 4). Soil phosphorus, percent of total biological soil crust cover, and percent bare ground had positive direct effects on B. tectorum distribution. The other 3 variables were significant only when considering the interaction with other identified variables, indicating that location (UTM-north), elevation, and herbaceous species richness may have only indirect effects on B. tectorum distribution (UTM-north and elevation had negative effects while herbaceous species richness had positive effects). Based on the results of prediction success indices, this model produced a gain of $7 \%$ over a purely random model for responses (B. tectorum present) and 28\% for reference cases (absent), with occurrence correctly predicted $80 \%$ of the time.

Erodium cicutarium (subdominant generalist): The logistic model identified 4 variables for predicting the presence of this annual forb (Table 4). Elevation and UTM-north and UTMeast coordinates had strong negative correlations with E. cicutarium distribution, while soil phosphorus had a strong positive correlation. This suggests the presence of this species in lower-elevation plots along the southwestern portion of the study area. The model explained $48 \%$ of the variation in E. cicutarium presence and correctly predicted occurrence $89 \%$ of the time.

Poa pratensis (specialist): Four variables explained $60 \%$ of the variation in $P$. pratensis distribution (Table 4). The significant variables in the logistic model were moisture index and transient $(<1 \%$ cover $)$ species richness with positive correlations, and topographic position and succulent species richness with negative correlations. These results predict the invasion of $P$. pratensis in lowland wash sites with fewer succulent species and more transient species. The model demonstrated a $54 \%$ gain over a purely random model for species presence and correctly predicted occurrence $92 \%$ of the time.

Salsola iberica (subdominant generalist): Elevation and UTM coordinates (north and east) were significant indicators for S. iberica and suggest greater occurrences in the lowerelevation, northwestern portions of the study area (Table 4). Total crust cover had a negative correlation and was significant only when considering the interaction with the other 3 identified variables. The model provided a $45 \%$ gain over a purely random model and correctly predicted occurrence $90 \%$ of the time (Table 4). 


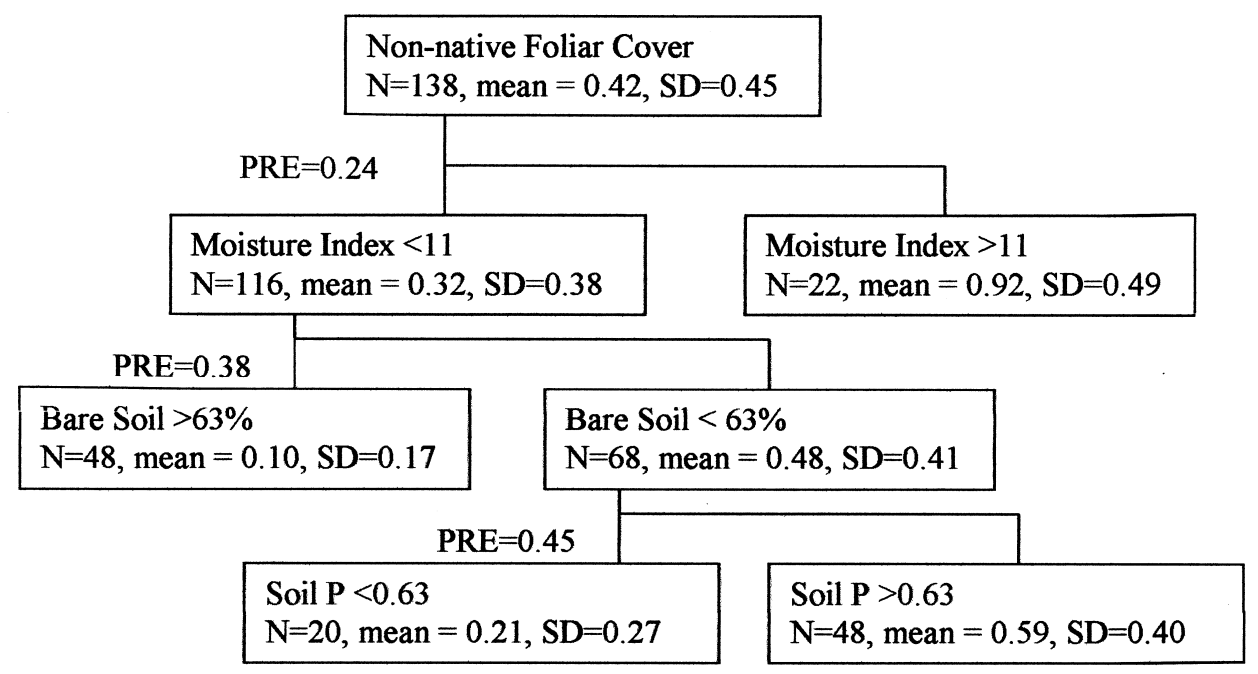

Fig. 3. Regression tree analysis with $\log _{10}$ Nonnative Foliar Cover as the dependent variable. Moist sites are most heavily invaded, while drier sites with less bare ground and less soil phosphorus are less heavily invaded.

Tamarix spp. (specialist): The logistic model identified 4 variables that are correlated with riparian areas including moisture index (strongly positive), UTM-north, elevation, and percent sand to distinguish plots invaded by Tamarix spp. (Table 4). All variables were significant except UTM-north, which was considered to be significant only when considering the interaction with the other 3 variables. Tamarix successfully invaded moist, lower elevation sites with sandy soils, and the model correctly predicted occurrence $93 \%$ of the time.

Taraxacum officinale (subdominant generalist): Soil phosphorous and moisture index were strongly, positively correlated with the presence of $T$. officinale. Plots with higher native species richness and less bare ground also had more T. officinale. The model explained $61 \%$ of the variation in T. officinale presence and correctly predicted occurrence $92 \%$ of the time (Table 4).

Tragopogon dubius (subdominant generalist): Soil phosphorus, elevation, and native species richness were all positively correlated with the occurrence of the 2nd most frequently encountered nonnative species in the Monument: T. dubius (Table 4). As with Taraxacum officinale, the model indicated weak positive effects of native species richness interacting with the other 2 significant variables. The model with the 3 variables produced correct results for $89 \%$ of the cases. The model for T. dubius produced the highest McFadden's Rho-squared value of 0.62 with the fewest number of variables among the 7 focal species.

\section{Discussion}

Plant Invasions from a Habitat Perspective

In this case study moisture index, soil phosphorus, and elevation were the most important indicators of nonnative plant invasions, explaining $50 \%$ of the variation. Other factors such as native species richness and topographic position have been found in other studies to be consistently strong predictors of nonnative species richness and cover (Robinson et al. 1995, Stohlgren et al. 1997, 1998b, 1999b, Chong et al. 2001a, 2001b). In our study areas nonnative plants were more successfully established in mesic sites at lower elevations with higher soil phosphorus.

Knowledge of these general patterns of plant invasions in the study area is important for resource managers as they make decisions regarding control of nonnative species, protection of native species diversity, and activities that might alter the opportunities for native and nonnative species establishment (e.g., disturbances such as fire, grazing, or off-highway vehicle use). The general patterns we found are alarming for several reasons. First, more 
TABLE 3. Mean plot frequency, habitat frequency, cumulative cover, and maximum foliar cover for the 4 invasive species groups. Standard errors are in parentheses. Means within each column were compared separately by invasive species group with 1 -way ANOVA; the $F$-ratio and $P$-value are listed. Values followed by a different letter within a column are significantly different.

\begin{tabular}{lccccc}
\hline $\begin{array}{l}\text { Invasive species } \\
\text { group }\end{array}$ & $\begin{array}{c}\text { Numbers } \\
\text { of species }\end{array}$ & $\begin{array}{c}\text { Plot } \\
\text { frequency }(\%)\end{array}$ & $\begin{array}{c}\text { Habitat } \\
\text { frequency }(\%)\end{array}$ & $\begin{array}{c}\text { Mean cumulative } \\
\text { cover }(\%)\end{array}$ & $\begin{array}{c}\text { Maximum foliar } \\
\text { cover per plot }(\%)\end{array}$ \\
\hline Dominant generalist & 1 & $80 \mathrm{a}$ & $93 \mathrm{a}$ & $379 \mathrm{a}$ & $94 \mathrm{a}$ \\
Subdominant generalist & 8 & $8(1.7) \mathrm{b}$ & $38(6.3) \mathrm{b}$ & $10(2.5) \mathrm{c}$ & $13(3.0) \mathrm{c}$ \\
Specialist & 6 & $7(1.2) \mathrm{b}$ & $32(4.8) \mathrm{b}$ & $25(6.9) \mathrm{b}$ & $60(5.4) \mathrm{b}$ \\
Transient & 19 & $2(0.3) \mathrm{c}$ & $12(1.8) \mathrm{c}$ & $3(0.8) \mathrm{c}$ & $5(1.6) \mathrm{c}$ \\
\hline$P$-value & - & 0.0001 & 0.0001 & 0.0001 & 0.0001 \\
$F$-ratio & - & 229.4 & 23.2 & 681.1 & 89.5 \\
\hline
\end{tabular}

heavily invaded habitats are also sites high in native species richness, soil phosphorus, and relative soil moisture (Table 2 ). Thus, any control efforts in these habitats would require care to reduce impacts to native species (Chong et al. 2001b) and, potentially, water resources. A similar pattern has been documented in the Rocky Mountains of Colorado (Stohlgren et al. 1999a, 1999b) and the Central Grasslands (Stohlgren et al. 1998a, 1999a). Second, relatively moist habitats such as riparian zones and aspen stands occupy a small proportion of the Monument landscape, and they contain unique assemblages of plants. These habitats are also more heavily invaded than common vegetation types such as blackbrush and pinyonjuniper. These results agree with other studies that found high-diversity areas supported by higher available resources are more susceptible to invasion (Hobbs and Huenneke 1992, Planty-Tabacchi et al. 1996, Stohlgren et al. 1998b, 1999a, 1999b, 2001, Lee 2001). Third, areas of low soil crust development and areas of low crust cover were the most heavily invaded. Although it was not directly measured in this study, low crust cover could be related to human-induced disturbances such as trampling by livestock or off-road vehicles. Disturbance is known to be correlated with nonnative plant species presence. Crust recovery from trampling can take decades (Belnap 1998), allowing ample opportunity for the establishment of nonnative species.

\section{Plant Invasions from a Species Perspective}

While the habitat perspective provides important information on the vulnerability of specific habitats to invasion, species-specific information is needed to target control efforts that often rely on species-specific biological controls or less specific chemical controls. Our results demonstrated the individualistic nature of plant species invasion patterns in the Monument, with some species showing higher predictability than others. Nonnative species that invade more diverse and fertile habitats were more easily identified in general models than those species that occupy drier, upland sites with various soil types.

Bromus tectorum was the most difficult species to predict due to its ability to colonize a wide range of habitats. This species was found in $93 \%$ of the plots. Throughout the study area the presence of $B$. tectorum was generally correlated with higher soil phosophorus and lower elevation-as were many other nonnative species. Surprisingly, B. tectorum was also positively correlated with higher crust cover, which is opposite the average nonnative species response. The other 6 focal nonnative species of concern were confined to fewer habitats, and so predictions of species occurrence based on logistic regression tended to be more accurate than the predictions for the generalist B. tectorum.

Although each nonnative species may have unique invasion patterns, some species appeared to share common general traits. Erodium cicutarium and Salsola iberica, for example, are both annual forbs that are often associated with disturbed habitats and were both classified as subdominant generalists in this study. Our logistic models showed that 3 location variables (UTM-east, -north, and elevation) could explain $35 \%$ of the variation for these species. Interestingly, the distributions of these 2 species did not overlap despite their shared favored habitat conditions: E. cicutarium occupied the northwestern portion of the study area while S. iberica occupied the southeastern portion. 
TABLE 4. Summary of logistic regression analyses for 7 focal nonnative species in Grand Staircase-Escalante National Monument. All models were significant at $P<0.001$. Total \% correct indicates the percentage of plots where occurrence was correctly predicted.

\begin{tabular}{|c|c|c|c|}
\hline Species & Predictor variables $(\mathrm{P})$ & $\mathrm{Rho}^{2}$ & $\begin{array}{l}\text { Total } \% \\
\text { correct }\end{array}$ \\
\hline $\begin{array}{l}\text { Bromus tectorum } \\
\quad \text { (Dominant generalist) }\end{array}$ & $\begin{array}{l}\text { Soil P }(0.001), \text { UTM-north }(0.065) \text {, elev. }(0.061), \% \text { bare } \\
\text { ground }(0.006), \% \text { crust cov. }(0.010), \text { herbaceous species } \\
\text { richness }(0.067)\end{array}$ & 0.34 & $80 \%$ \\
\hline $\begin{array}{l}\text { Erodium cicutarium } \\
\quad \text { (Subdominant generalist) }\end{array}$ & $\begin{array}{l}\text { Elev. (0.001), soil P (0.002), UTM-north (0.001), UTM-east } \\
\quad(0.004)\end{array}$ & 0.48 & $89 \%$ \\
\hline Poa pratensis (Specialist) & $\begin{array}{l}\text { Topo. position }(0.001) \text {, moist. index }(0.002) \text {, low cover } \\
\text { richness }(0.001) \text {, succulent species richness }(0.004)\end{array}$ & 0.60 & $93 \%$ \\
\hline $\begin{array}{l}\text { Salsola iberica } \\
\quad \text { (Subdominant generalist) }\end{array}$ & $\begin{array}{l}\text { Elevation }(0.016), \text { UTM-north }(0.052) \text {, UTM-east }(0.005) \text {, } \\
\% \text { crust cover }(0.066)\end{array}$ & 0.42 & $90 \%$ \\
\hline Tamarix spp. (Specialist) & $\begin{array}{l}\text { Moist. index }(0.004) \text {, UTM-north }(0.07) \text {, elev. }(0.002) \text {, } \\
\text { \% sand }(0.029)\end{array}$ & 0.61 & $93 \%$ \\
\hline $\begin{array}{l}\text { Taraxacum officinale } \\
\quad \text { (Subdominant generalist) }\end{array}$ & $\begin{array}{l}\text { Soil P }(0.001) \text {, moist. index }(0.001) \text {, native species rich. } \\
\quad(0.091), \% \text { bare ground }(0.157) \text {. }\end{array}$ & 0.61 & $92 \%$ \\
\hline $\begin{array}{l}\text { Tragopogon dubius } \\
\quad \text { (Subdominant generalist) }\end{array}$ & Soil P (0.001), elev. (0.016), native species richness $(0.146)$. & 0.62 & $89 \%$ \\
\hline
\end{tabular}

Two subdominant generalist species, Taraxacum officinale and Tragopogon dubius, also demonstrated similar habitat preferences. The presence of both species showed strong positive relationships to sites with higher soil phosphorus, which made it the single most significant variable in any of the models for the 2 species, explaining $46 \%$ of the variation. The inclusion of native species richness in the models resulted in the explanation of $51 \%$ of the variation for T. officinale and $49 \%$ for $T$. dubius. Although these species rarely dominate the landscape, they are both known for their ability to establish in a wide range of environmental conditions due to prolific reproduction, many adaptive biotypes, and effective seed dispersal mechanisms (Holm 1997, Clements et al. 1998).

Overall, relatively few habitat characteristics (3-6 variables) provided good predictability for the presence of each focal species. This suggests that the same field data used to evaluate habitat vulnerability to invasion can be used to predict the occurrence of most highly invasive species in the study area. Such information can be used to target noxious species for control, such as Tamarix spp., whose occurrences can be predicted correctly $93 \%$ of the time.

\section{Management Implications of this Approach}

We tested an approach to evaluate speciesenvironment relationships at landscape scales to address 2 important and general aspects in the management and control of invasive species: (1) identifying which habitats have been most heavily invaded, and (2) identifying which species have been the most successful invaders. The habitat perspective allows land managers to set priorities for future surveys and monitoring. Our research, and corroborating studies (Stohlgren et al. 1998a, 1999a, 1999b, 2001), have shown that mesic habitats in the Monument and throughout the western Great Plains, the Rockies, and the Colorado Plateau may be the most vulnerable to invasion. From the species perspective we found that most nonnative species are locally rare transients (19 of 34 species had $<1 \%$ cover). Only a few invading plants in a given area may have significant effects on natural resources, and thus new research and analytical tools are needed to identify which species are causing significant impacts currently and which species may cause significant impacts in the future (Hiebert 1997).

Our general predictive models were able to explain $60 \%$ and $46 \%$, respectively, of the variation in nonnative species richness and cover in a complex landscape with relatively modest sampling intensity $(<1 \%$ of the landscape). Species-specific logistic regression models for the 7 focal invasive species also provided useful tools to characterize species-specific habitat preference in the Monument, predicting $89 \%$ of invaded sites on average. Therefore, our most important finding was that the same 
multiscale sampling design used to evaluate habitat vulnerability to invasion in a large landscape also provided information to predict the occurrence of the most highly invasive species in the study area.

A possible approach for researchers and managers in other study areas could proceed as follows. First, existing landscape data could be used to develop an initial stratification for plot sampling based on a combination of current, dominant vegetation (e.g., vegetation map), topography (e.g., slope, aspect, elevation), and land use (e.g., roads, trails, grazing regimes). A working hypothesis to guide sampling could be that more nonnative species will be found in species-rich areas (determined based on the vegetation map), lower elevation and more moist areas, and areas with greater disturbance. Numbers and locations of plots should be determined based on available resources, existing knowledge, and management objectives. It is better to collect a small amount of quality data each season than no data at all because a single, large-scale investigation is too expensive. Second, data would be compiled and analyzed as in this paper. Third, results from the first 2 steps could be used in an adaptive management framework where future sampling is directed by results and the development of new questions and hypotheses generated from previous data and management actions (e.g., control efforts).

This approach of multiscale sampling and evaluating plant invasions from habitat and species perspectives may be generally applicable in many natural landscapes and can provide land managers with a tool for focusing inventory, monitoring, and controlling invasive species. This ability to increase focus is important because patterns of invasion are expected to change over time based on several factors that include (1) time since the invasion began, past and current land use practices, and climate (Mack et al. 2000); (2) initial failure to capture an "invasion window" (Johnstone 1986) where a species is not noticed until it becomes widespread (Hobbs and Humphries 1995); (3) adaptation of the invading species to a wide range of environmental tolerances (Mack 1981); and (4) change of habitats following natural disturbances or change of land uses (Evangelista 2002).

\section{ACKNOWLedgments}

The authors thank Tom Leatherman and Grand Staircase-Escalante National Monument staff for assistance in project coordination and site selection, and the field crew (Jeanette Haddock, Michele Hart, Amber Hughes, Jeanne Leatherman, Michelle Lee, Dennis McCrumb, John Moeny, Seth Ohms, Anne Overlin, Nate Pierce, Rick Shory, and Sean Stewart) for their dedicated data collection. Michael Bashkin provided the soil analyses. Kelly Rimar and Jayne Belnap provided earlier reviews of this manuscript. Financial support was provided by the U.S. Department of Interior, Bureau of Land Management. Logistical support was provided by the U.S. Geological Survey (Fort Collins Science Center) and the Natural Resource Ecology Laboratory, Colorado State University. To all we are grateful.

\section{Literature Cited}

Barrett, S.C.H., And B.J. Richardson. 1986. Genetic attributes of invading species. Pages 21-33 in R.H. Groves and J.J. Burdon, editors, Ecology of biological invasions. Cambridge University Press, Cambridge, U.K.

BELNAP, J. 1998. Impacts of trampling soils in southeast Utah ecosystems. Pages 231-244 in L.M. Hill, editor, Learning from the land, Grand Staircase-Escalante National Monument science symposium. Paragon Press, Salt Lake City, UT.

BuRKE, M.J., AND J.P. GRIME. 1996. An experimental study of plant community invasibility. Ecology 77:776-790.

CASE, T.J. 1990. Invasion resistance arises in strongly interacting species-rich model competition communities. Proceedings of the National Academy of Science 87:9610-9614.

Chong, G.W., R.M. Reich, M.A. Kalkhan, and T.J. StOhLGREN. 2001a. New approaches for sampling and modeling native and exotic plant species richness. Western North American Naturalist 61:328-335.

Chong, G.W., S.E. Simonson, T.J. Stohlgren, and M.A. Kalkhan. 2001b. Biodiversity: Aspen stands have the lead, but will nonnative species take over? Pages 261-271 in W.D. Shepperd, D. Binkley, D. Bartos, T.J. Stohlgren, and L.G. Eskew, compilers, Sustaining aspen in western landscapes. Symposium proceedings, 13-15 June 2000, Grand Junction, CO. Proceedings RMRS-P-18, U.S. Department of Agriculture, Forest Service, Rocky Mountain Research Station, Fort Collins, CO. 460 pp.

Clements, D.R., M.K. Upadhyaya, and S.J. Bos. 1998. The biology of Canadian weeds. 110. Tragopogon dubius Scop., Tragopogon pratensis L. and Tragopogon porrifolius L. Canadian Journal of Plant Science 79:153-163.

Crawley, M.J. 1987. What makes a community invasible? Pages 429-451 in A.J. Gray, M.J. Crawley, and P.J. 
Edwards, editors, Colonization, succession, and stability. Blackwell Scientific Publications, Oxford, U.K.

Cronk, C.B., AND J.L. Fuller. 1995. Plant invaders: the threat to natural ecosystems. Chapman and Hall, London.

D’Antonio, C.M. 1997. Introduction. In: J.O. Luken and J.W. Thieret, editors, Assessment and management of plant invasions. Springer-Verlag, New York.

D’Antonio, C.M., And P.M. Vitousek. 1992. Biological invasions by exotic grasses, the grass/fire cycle, and global change. Annual Review of Ecological Systematics 23:63-87.

Davis, M.A., J.P. Grime, And K. Thompson. 2000. Fluctuating resources in plant communities: a general theory of invasibility. Journal of Ecology 88:528-534.

DeFerrari, C.M., and R.J. Naimen. 1994. A multi-scale assessment of the occurrence of exotic plants on the Olympic Peninsula, Washington. Journal of Vegetation Science 5:247-258.

Elton, C. 1958. The ecology of invasions by animals and plants. Methuen and Company, Ltd., London.

Evangelista, P. 2002. Vegetation response following postburn seeding treatments in the Grand StaircaseEscalante National Monument, Utah. Master's thesis, Colorado State University, Fort Collins.

Fox, M.D., AND B.J. Fox. 1986. The susceptibility of natural communities to invasion. Pages 57-66 in R.H. Groves and J.J. Burdon, editors, Ecology of biological invasions. Cambridge University Press, Cambridge, U.K.

Gee, G.W., And J. Bauder. 1986. Particle size analysis. Pages 383-411 in A. Klute, editor, Methods of soil analysis. Part 1 , Physical and mineralogical methods. ASA, Madison, WI.

Hansen, M.R., R. Dubayah, and R. Defries. 1996. Classification trees: an alternative to traditional land cover classifiers. Journal of Remote Sensing 17:1075-1081.

Hensher, D.A., and L.W. Johnson. 1981. Applied discrete-choice modeling. John Wiley and Sons, New York.

Hiebert, R.D. 1997. Prioritizing invasive plants and planning for management. Pages 195-212 in J.O. Luken and J.W. Thieret, editors, Assessment and management of plant invasions. Springer-Verlag, New York.

Hoвbs, R.J. 1991. Disturbance a precursor to weed invasion in native vegetation. Plant Protection Quarterly 6:99-104.

Hobbs, R.J., and L.F. Huenneke. 1992. Disturbance, diversity, and invasion: implications for conservation. Conservation Biology 6:324-335.

Hobbs, R.J., And S.E. Humphries. 1995. An integrated approach to the ecology and management of plant invasions. Conservation Biology 9:761-770.

HoLm, L. 1997. World weeds: natural histories and distribution. Wiley, New York

Johnstone, I.M. 1986. Plant invasion windows: a timebased classification of invasion potential. Biological Review 61:369-394.

Kou, S. 1996. Phosphorous. Pages 869-920 in D.L. Sparks, editor, Methods of soil analysis. Part 3, chemical methods. Soil Science Society of America, Madison, WI.

LEE, M. 2001. Non-native plant invasions in Rocky Mountain National Park: linking species traits and habitat characteristics. Master's thesis, Colorado State University, Fort Collins.
LODGE, D.M. 1993. Biological invasions: lessons for ecology. Trends in Ecology and Evolution 8:133-137.

LODGE, G.M. 2000. Effects of sowing method and competitor species and presence on Phalaris and Austrodanthonia establishment and persistence. Australian Journal of Experimental Agriculture 40:813-823.

LONSDALE, W.M. 1999. Global patterns of plant invasions and the concept of invasibility. Ecology 80:1522-1536.

MACK, R.N. 1981. Invasion of Bromus tectorum L. into western North America: an ecological chronicle. Agro-Ecosystems 7:145-165.

Mack, R.N., D. Simberloff, W.M. Lonsdale, H. Evans, M. Clout, And F. Bazzaz. 2000. Biotic invasions: causes, epidemiology, global consequences and control. Issues in Ecology 5:1-19.

Newsome, A.E., AND I.R. Noble. 1986. Ecological and physiological characters of invading species. Pages 1-15 in R.H. Groves and J.J. Burdon, editors, Ecology of biological invasions. Cambridge University Press, Cambridge, U.K.

Office of Technology Assessment (OTA), U.S. ConGRESS. 1993. Harmful non-indigenous species in the United States. OTA-F-565, U.S. Government Printing Office, Washington, DC.

Panetta, F.D., And N.D. Mitchell. 1991. Homoclime analysis and the prediction of weediness. Weed Research 31:273-284.

Pimentel, D., L. Lach, R. Zuniga, and D. Morrison. 2000. Environmental and economic costs of nonindigenous species in the United States. BioScience 50:53-65.

Planty-Tabacchi, A.-M., E. Tabacchi, R.J. Naiman, C. DEFERRARI, AND H. DECAMPS. 1996. Invasibility of species-rich communities in riparian zones. Conservation Biology 10:598-607.

REJMÁNEK, M. 1989. Invasibility of plant communities. Pages 369-388 in J.A. Drake, H.A. Mooney, F. di Castri, R.H. Groves, FJ. Kruger, M. Rejmánek, and M. Williamson, editors, Biological invasions: a global perspective. John Wiley and Sons, New York, New York.

Rejmánek, M., And M.J. Pitcairn. 2002. When is eradication of exotic pest plants a realistic goal? Pages 249253 in C.R. Veitch and M.N. Clout, editors, Turning the tide: the eradication of invasive species. IUCN SSC Invasive Species Specialist Group, IUCN, Gland, Switzerland.

Robinson, G.R., J.F. Quinn, and M.L. Stanton. 1995. Invasibility of experimental habitat in California winter annual grassland. Ecology 79:786-794.

Roy, J. 1990. In search of the characteristics of plant invaders. Pages 335-352 in F. di Castri, A. Hansen, and M. Debussche, editors, Biological invasions in Europe and the Mediterranean Basin. Kluwer Academic Publishers, Dordrecht, Netherlands.

ShulTZ, L.M. 1998. The flora and fauna of the Colorado Plateau: What do we know? Pages 203-210 in L.M. Hill, editor, Learning from the land, Grand Staircase-Escalante National Monument science symposium. Paragon Press, Salt Lake City, UT.

Stohlgren, T.J., M.B. Coughenour, G.W. Chong, D. Binkley, M.A. Kalkhan, L.D. Schell, D.J. BuckLEY, AND J.K. BERRY. 1997. Landscape analysis of plant diversity. Landscape Ecology 12:155-177.

Stohlgren, T.J., K.A. Bull, and Y. OTsuki. 1998a. Comparison of rangeland vegetation sampling techniques 
in the Central Grasslands. Journal of Range Management 51:164-172.

Stohlgren, T.J., K.A. Bull, Y. Otsuki, C.A. Villa, And M. LEE. 1998b. Riparian zones as havens for exotic plant species in the Central Grasslands. Plant Ecology 138:113-125.

Stohlgren, T.J., D. Binkley, G.W. Chong, M.A. Kalkhan, L.D. Schell, K.A. Bull, Y. Otsuki, et AL. 1999a. Exotic plant species invade hot spots of native plant diversity. Ecological Monographs 69:25-46.

Stohlgren, T.J., L.D. Schell, and B. Vanden Heuvel. 1999b. How grazing and soil quality affect native and exotic plant diversity in Rocky Mountain grasslands. Ecological Applications 9:45-64.

Stohlgren, T.J., Y. Otsuki, C.A. Villa, M. Lee, and J. Belnap. 2001. Patterns of plant invasions: a case example in native species hotspots and rare habitats. Biological Invasions 3:37-50.

Swincer, D.E. 1986. Physical characteristics of sites in relations to invasions. Pages $67-76$ in R.H. Groves and J.J. Burdon, editors, Ecology of biological invasions. Cambridge University Press, Cambridge, U.K.

SYSTAT SOFTWARE, INC. (SSI). 1999. Systat, version 9. SSI, Richmond, CA.

Tilman, D. 1999. The ecological consequences of changes in biodiversity: a search for general principles. Ecology 80:1455-1474.
U.S. Department of the Interior (USDI). 1995. Visitor experience and resource protection implementation plan. NPS D-70. National Park Service, Denver, CO.

Usher, M.B. 1988. Biological invasions of nature reserves: a search for generalizations. Biological Conservation 44:119-135.

Vitousek, P.M., C.M. D’Antonio, L.L. Loope, M. RejmáneK, AND R. Westbrooks. 1997. Introduced species: a significant component of human-caused global change. New Zealand Journal of Ecology 21:1-16.

Wagner, S.W., J.D. Hanson, A. Olness, and W.B. VoorHEES. 1998. A volumetric inorganic carbon analysis system. Soil Science Society of America Journal 62:690-693.

Welsh, S.L., N.D. Atwood, S. GoOdrich, AND L.C. HigGINS. 1993. A Utah flora. 2nd edition. Jones Endowment Fund, Provo, Utah.

Williamson, M., AND A. FitTer. 1996. The varying success of invaders. Ecology 77:1661-1666.

Received 20 April 2004 Accepted 7 April 2005 